\title{
The Scythian Stag in Contemporary Arts and Craft: Tuva and Abroad
}

\author{
Katherine Zeahan Leung \\ Independent scholar, USA
}

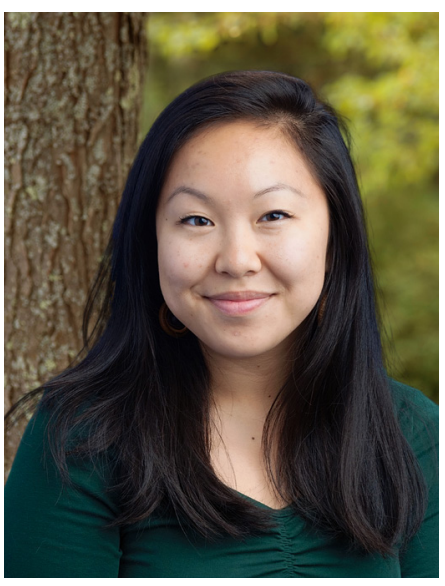

The article examines the interest in Scythian imagery and motifs in contemporary arts and crafts, both in Tuva and outside Russia, on a surge after the excavation of Arzhan II burial site. As proved by numerous references, the most popular of the Arzhan II finds was the stylized image of the Scythian stag on a golden hair pin. It has since appeared on the photo taken by Russian photographer Andrei Bronnikov, whose main subject is jewelry. Tattoo artists in English-speaking regions have seen an uptick in customers requesting Scythian stag tattoo designs, due in large part to the discovery of the popularly dubbed "Ukok Princess" and increase in interest in prehistoric fantasy media. Russian-speaking fashion designers redefine textile and ornament in the twenty-first century, influenced by the golden accents of the looped stag in their work, at times inventing an embellished narrative of the past. Folk crafters have created costume and jewelry designs for a different world they wish to inhabit, even creating alter-egos and stories that accompany Scythian-inspired pieces. Finally, within Tuva, wood carving continues thanks to trailblazers that promote folk handicrafts through education and archival work.

Artists around the world are fascinated by this unique relic of the past and employ the symbol in romantic imaginings of their past and present.

Keywords: Scythian gold; Scythian stag; Scythian imagery; Tuva; Tuvan culture; contemporary art; photography; tattoo; folk art; fashion; national costume; textile; wool felt; lapidary; wood carving

\section{For citation:}

Leung K. Z. The Scythian Stag in Contemporary Arts and Craft: Tuva and Abroad. New Reasearch of Tuva, 2021, no. 1, pp. 91-106. DOI: https://www.doi.org/10.25178/nit.2021.1.5 


\title{
Скифский олень в современном искусстве и ремесле: Тува и зарубежье
}

\author{
Кэтрин З. Лунг \\ Независимый исследователь, США
}

\begin{abstract}
В статье рассматривается интерес к скифским образам и сюжетам в современном искусстве и ремеслах Тувы и зарубежья, который возник после археологического открытия захоронений в Аржан II в Туве. При этом самым востребованным образом оказалось стилизованное изображение скифского оленя. Это показывается на примерах из разных видов искусства и ремесел. Например, известно изображение оленя на золотой заколке для волос, которое было сделано российским фотографом, специалистом по ювелирной фотографии Андреем Бронниковым. Тату-художники в англоязычных странах наблюдают всплеск запросов клиентов, которые хотят сделать себе татуировки скифского оленя. Русскоязычные модельеры переосмысливают текстиль и орнамент в ХХІ веке под влиянием золотых акцентов закольцованного оленя в своих работах, порой изобретая приукрашенное повествование о прошлом. Народные ремесленники создают украшения, вдохновленные скифскими образами. Наконеи, в самой Туве продолжает развиваться резьба по дереву и по камню, в которых мастера отдают дань уважения предкам, сплетая скифские символы с ремесленными традициями.

Художники всего мира очарованы этой уникальной реликвией прошлого и используют этот символ в романтических фантазиях о своем прошлом и настоящем.
\end{abstract}

Ключевые слова: скифское золото; скифский олень; скифский образ; Тува; тувинская культура; современное искусство; фотография; татуировка; высокая мода; национальный костюм; резьба по дереву № 1. C. 91-106. DOI: https://www.doi.org/10.25178/nit.2021.1.5

\section{Introduction}

Over 3000 pieces of gold are currently housed in the Tuvan National Museum, offering a wealth of insight into the rituals and culture of ancient Scythia (Armbruster, 2009). Excavations prior to the discovery at the Arzhan II kurgan share similar depictions of the same animals (Farkas, 1977: 126). Notable items from the Tuvan excavation are stylized animal reliefs and lost-wax casts on jewelry and other decorative objects, depicting local animals such as panthers, frogs, ibex, bears, and stags. The finding with the largest popular culture following is a golden stag, at the end of a 35-centimeter-long hairpin. "The significance of the deer to the Scythians might have been that of a tribal symbol. According to some Soviet scholars, the name Saka, the Iranian word for Scythian, can be interpreted as stag or antler”, perhaps the animal was an icon or spiritual symbol (Ibid.: 127).

The stag depicted in this specific pose is found on belt buckles, adorning funerary carts, breastplates, and on numerous other art objects, archived in the Tuvan National Museum. The stag is similar to many found in other burial sites, predominantly featuring a head that "rests on the coupe of its disproportionately short body. Only two feet are given, neatly juxtaposed in strict side-view, while the antlers, resembling tentacles, form a fantastic symmetrical pattern" (Loehr, 1955: 66). The stag looks to be in motion, muscles tight, giving the impression of speed. The antlers are looped, and thise most distinctive feature of all is not found on Chinese images of deer. "The stag's post, in which the legs overlap, is a characteristic leg position for representing ungulates that had enveloped throughout the Eurasian steppes by the early first millennium BC. Such a pose can be seen on many deerstones found throughout southern Siberia and Mongolia" (Bunker, 2002: 17), which is the most notable characteristic of the Tuvan excavation, worthy of recreating over and over again in contemporary reimaginations. Archivists and excavators has done much of the legwork in collecting, cataloging, and describing these symbols. Archivists have put together much about Scythian 
metalwork and burial practices. Folklorists have described the historical cultural consequences of these symbols. Photographers have captured the likeness, so that artists have ready access to it.

Indeed there is wealth of existing scholarship about workmanship and imagery, but my research pertains to this symbol in contemporary art, both in Tuva and outside of the republic. Some symbols hold a heavier weight, culturally and artistically. The Scythian stag is one such symbol. It is time-period specific and evokes a certain idea, more than horses, yurts, or Buddhist symbols and their capabilities. I am interested in how this symbol, coming from a prehistoric burial mound in modern Tuva, can permeate cultural and linguistic barriers. Outside of Central Asia, not much about steppe or nomad life is known. Even less is known about Scythian life outside of academic circles. Because of this, my research pertains manifestations of the stag symbol in contemporary and fine arts. I am interested in how regular people react to and use this symbol. I use online resources to explore photography, tattoo art, folk costumes, and folk arts have used this symbol. I explore Instagram sites, Etsy shops, and Vkontakte pages of artists and designers worldwide, noticing how they utilize the symbol for self-expression, romantic reimagining of the past, and at times, profit.

The scientific relevance across cultures is important because academic discourse has long excluded the work of outside interpretation. It has also excluded contemporary folk crafts, as they are seen too commercial and transcend cultural purity. I gathered evidence for this article through interviews. I spoke with Tuvan tattoo artist Alexander Mongush and New Zealander tattoo artist Danny Riday to find out more about Scythian imagery in tattoo art inside and outside Tuva. I found these tattoo artists through their social media pages and conducted the interviews through direct messaging on their respective platforms. This is also how I located the work of Christine Wild and Foodieknitter's personal tattoo.

I also interviewed Hungarian-Australian folk artist Boroka Égerházi-Kis on August 23 $3^{\text {rd }}, 2020$ through social media to find out her inspiration and motivation behind creating a Scythian stag mask, which she proudly entered into an international wearable art competition. While I did not conduct an interview with Vycheslav Dongak, Elena Godis, and Aliza Souleyeva-Alexander, all three are Russian-speaking artists that use the stag in their work. I located all these folk artists through searches using hashtags such as \#ScythianStag \#Scythianculture and variations of these words during the month of August 2020.

As an American, it was within my realm to search and communicate through social media. What was more difficult was locating sources within Tuva that use this symbol. I was able to find the furniture-building contest, explored in the last part of this article, and other Tuvan artisans that are considered precursors in modern Tuvan folk art. Within Tuva, there is a strong tradition of folk art and carving. The carving contest, held through a local university, is merely a modern-day practice that follows the precedent set by artists like Hertek Kashtayovich Toubuhaa, Cherzi Mongush, Dongak Okaanchik and contemporary collector Maxim Ochur-Badievich Lopsan, all of whom drawfrom local flora and fauna, and uselocal wood and stone as art making materials is an established tradition.

Within Tuva, the symbol of the Scythian stag is revered in modern times. The National Museum of Tuva currently displays a graphic recreation of the stag in its logo and on all official merchandise and messaging. The stag was used in an international forum "Intellectual Gold of Eurasia" for entrepreneurship, tourism, national and global security, and green energy, held in Kyzyl in 2015². The stag is surely a memorable symbol, rooted in both fantasy and native fauna of the region, and is implemented in many official ways.

The reason that this stag continues to fascinate outside of Tuva is because it is highly replicable. It is not an invented symbol, it has prehistoric roots, which is why artists continue to draw from it. This article explores multiple examples of how the stag is used. Merely observing a trend is the initial step. In my research, I break down reasons why people are drawn to it and replicate it. I explain how they have used it and show images of their work. I speak to artists that talk about the personal relevance in their own ancestral imagining. I also speak to artists who have seemingly no connection, but in modernity, find ties to it because of recent trends in pop culture.

The Scythian stag is used by artists and meant to be shared publicly. Every photo in this article is located from social media pages, cross-fertilizing self-expression and self-promotion needs in a twenty-first century working artist. Social media plays a role in the self-identity process. Artists find themselves in the Scythian stag and are excited to educate. This article explores exactly how the Scythian stag is manifested. It is a dialogue between artists as much as it is a fantastic exhibition of talent.

${ }^{1}$ Хомушку В. Участники I Международного форума «Интеллектуальное золото Евразии» будут искать в Туве скифского Золотого Оленя [Электронный ресурс] // Тува.Азия. 2015, 5 сентября. URL: https://www.tuva.asia/ news/tuva/8206-zoloto-evrazii.html (accessed 22.08.2020). 


\section{The Scythian Stag in Photographic Depictions}

Since speculation about the stag is restricted to archaeology and despite the breadth of large-scale finds like the one in Tuva, meaning is found in romantic reimagination of the past and the people that came before. Artists in many spheres including tattoo, fashion, folk art, and carving are influenced by the looped stag of the Arzhan II excavation use the image to retell stories about themselves and others. In this article I highlight the creations of artists around the world that have found affinity to the Scythian stag through contemporary, modern, and folk art. Exploring what cultural products come out of the looped stag motif is important in understanding the narrative capabilities of this simple symbol. Artists participate in cultural reimagining all the time, especially of cultures that are mythological in nature.

Perhaps the most famous portrayal of the gold pieces themselves in the digital age is in the artwork of photographer Andrei Bronnikov. His work memorializes much of the artifacts from Arzhan II, making it accessible for outsiders without direct access to the archived gold pieces (photo 1). Study of contemporary craft in Western countries is not possible without the photos of Bronnikov. Known mostly as a commercial photographer, Bronnikov has shot for L'Officiel, Vogue, GQ, Harper's Bazaar, AD, Robb Report, Glamour, Elle and dozens of other publications. Most recognize Bronnikov by his work and not by name, on Channel One and in numerous international advertising campaigns. Bronnikov is Russia's top specialist in product and jewelry photography. Originally from Krasnoyarsk, a graduate of Moscow State University Geological Faculty, and with already decades of geological research experience, Bronnikov turned to commercial and art photography in 1995, though his background in geology gives him the distinct insight for capturing accuracy for archival purposes.

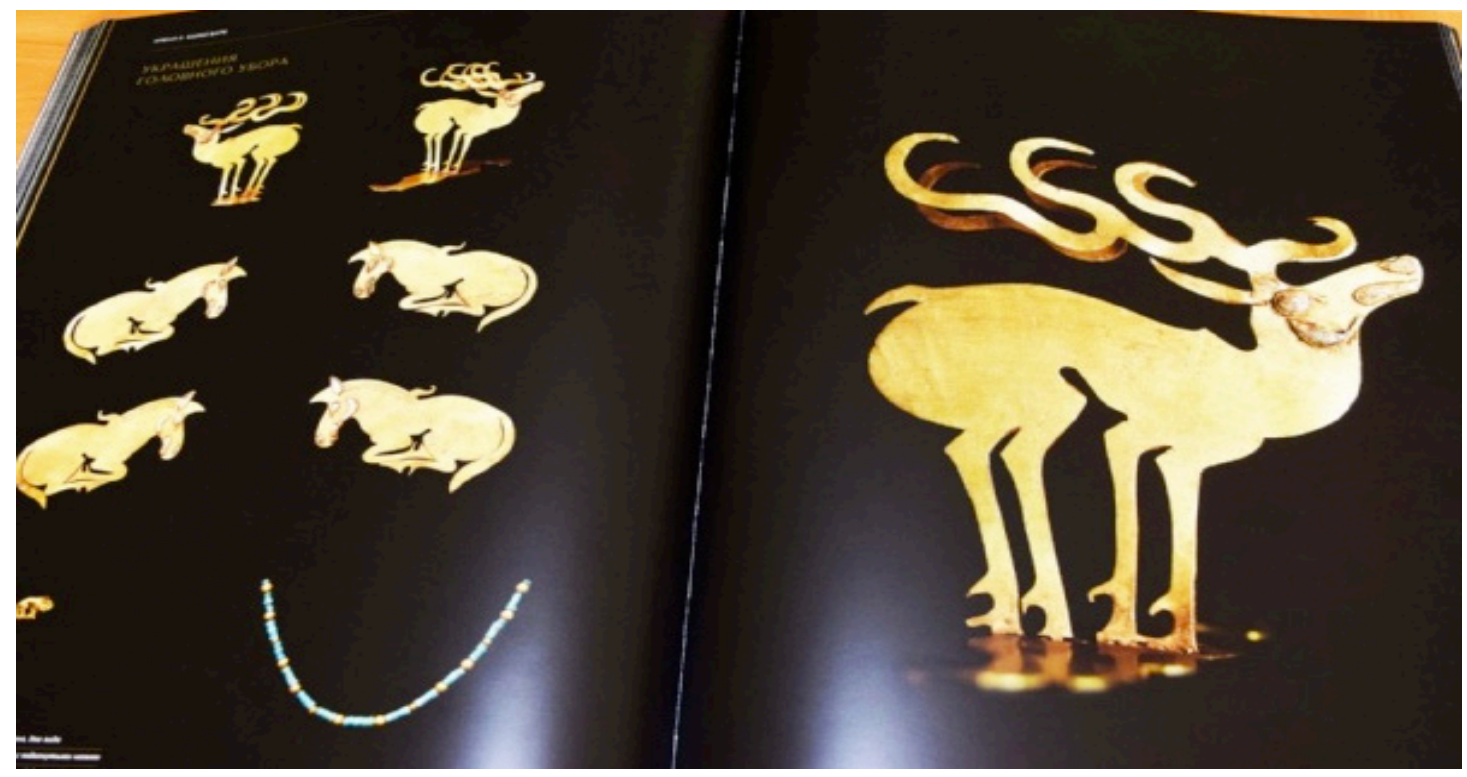

Photo 1. Image of Andrei Bronnikov's photo album for "Valley of the Kings of Tuva" exhibition, Kuzhuget Shoigu Cultural Foundation of Tuva.

Фото 1. Фотоальбом выставки Андрея Бронникова «Сокровища долины царей Тувы», Культурный фонд имени Кужугета Шойгу.

In 2014, Bronnikov was commissioned by the Kuzhuget Shoigu Cultural Foundation to depict gold jewelry uncovered from Arzhan II. Bronnikov's photos are collected in an international traveling exhibit called "Treasures of the Valley of the Tuvan Kings". Impressive large format photos that magnify every detail starkly sit against black velvet, digitally sharpened and exposure enhanced to depict every intricate detail of individual gold pieces. As that of a photographer, Bronnikov's work gives back more to the archeology and archival community than any other living artist. His Tuvan Kings photo collection is critically acclaimed in every city the exhibition took place, especially in Kyzyl. His photographs make archeological discovery possible for the everyday person, away from the burial sites, even more equitable with social media. 


\section{The Scythian stag in tattooing}

Other than photography, the stag is represented in many other art forms. While the popularity may be attributed to a variety of reasons, it may be due to the rise of ancient mythological TV shows like Game of Thrones in English speaking countries. One possible parallel is seen in the work of American tattoo artist, Christi Wild of Connecticut-based Silence is Golden Gallery in 2020. She created a Scythian stag tattoo for a client (photo 2). Inspired by the traditional golden design, her tattoo is comprised of thick, clean linework, bold like a block print. On Instagram, she writes "A modern take on the ancient. This is one of the designs found on the Ukok Princess aka the Siberian ice maiden, scroll for photos of the 2,500-year-old mummy and her preserved tattoos!" Her second slide is a meme and photograph of the remains dubbed the "Ukok Princess" in pop culture and to archaeologists. It is a specimen of a $5^{\text {th }}$ century woman, around twenty-five years of age, immaculately preserved by permafrost, and discovered in 1993 by Novosibirsk scientist Natalia Polosmak during an archeological expedition. Interestingly, the specimen's tattoos are still evident, clearly visible, and have been digitally recreated by Elena Shumakova of the Institute of Archeology and Ethnography, Siberian Branch of Russian Academy of Science. Wild simply recreated this drawing, to the same arm and placement as the Ukok Princess, who is still kept in a glass sarcophagus as the Republican National Museum in the regional capital, Gorno-Altaisk ${ }^{2}$. Unlike the stag found in Arzhan II, the hind legs are splayed in the air, though the decorative horns are still present.

As Wild's biography states, Christi is a self-taught artist born and raised in the Los Angeles San Fernando Valley. Her interests refer to oddities of nature, magic symbols, death and the macabre reflect on her art. She has been deeply influenced Latin and European folklore, and a background in anthropology only strengthens these ties. Now residing in Connecticut, she is one of the few practicing vegan tattooers and prides herself in providing a completely vegan procedure and aftercare for your comfort $^{3}$. Although she partakes in a millennia-old tradition of tattooing, her methods are completely original, updated to support a modern clientele.

In other English-speaking countries, people look to tattoo artists for Scythian stag designs. At Skinks Tattoo in New Zealand, one of the eight-artist team members is Danny Riday, an "intentional historical-tattoo artist" who specializes in "symbolically-significant, imaginative-imagery" through hand-poke, hand-tap, and relief tattooing methods ${ }^{4}$. Hehas created a variety of Scythian designs depicting animals.

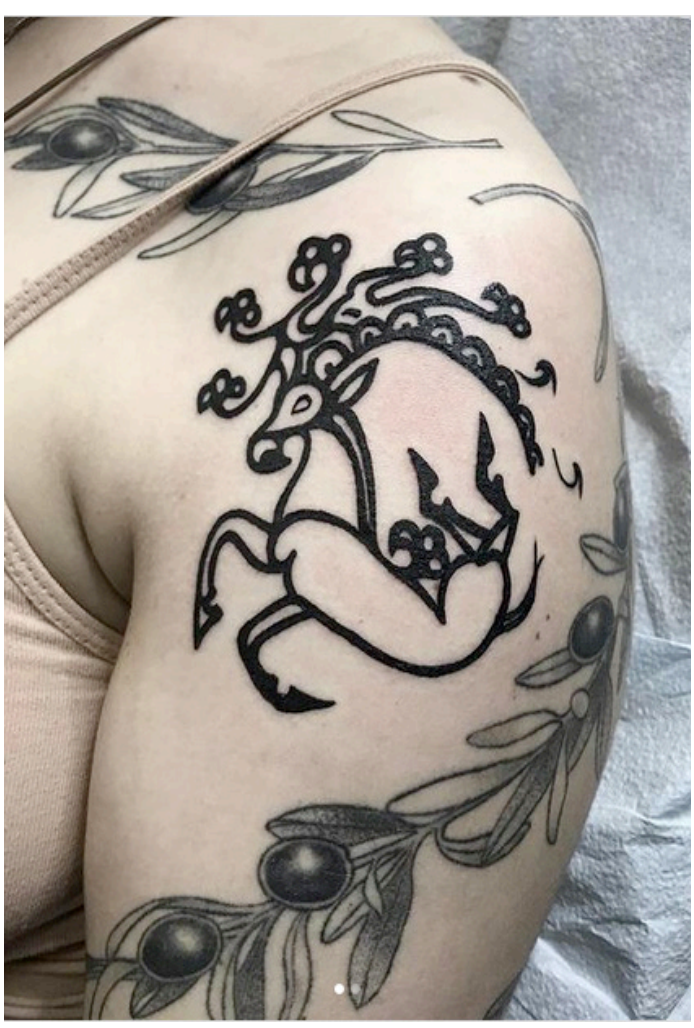

Photo 2. Scythian stag tattoo from Christi Wild's social media page Instagram.

Фото 2. Татуировка в виде скифского оленя, фото со страницы Кристи Уайлд в Инстаграме. Scythian tattoo designs are rising in popularity as more people become interested in Scythian history, storytelling, and anthology.

In an interview with Danny Riday that I conducted on August 23rd 2020, Riday says that clients that come into his tattoo shop desire Scythian tattoos for a variety of reasons. Scythian designs, like those that come from other ancient cultures such as Maori, Celtic, or Polynesian "have great appeal to Westerners who -

${ }^{1}$ Wild, Ch. Silence is Golden Gallery // Instagram, 26 July 2020 [online] Available at: https://www.instagram.com/p/ $\mathrm{CDHC}-1 \mathrm{HJ} \mathrm{mPj} /$ (accessed 22.08.2020).

${ }^{2}$ Siberian Princess reveals her 2,500 year old tattoos // The Siberian Times. 14 August 2012 [online] Available at: https://siberiantimes.com/culture/others/features/siberian-princess-reveals-her-2500-year-old-tattoos/ (accessed 22.08.2020).

${ }^{3}$ Artist | Christi Wild // Silence is Golden Gallery [online] Available at: https://www.silenceisgoldengallery.com/christi (accessed 22.08.2020).

${ }^{4}$ Riday, D. Hamilton, New Zealand // Instagram, 3 August 2020. URL: https://www.instagram.com/p/CDdPwVvFSnX/ (accessed 22.08.2020). 


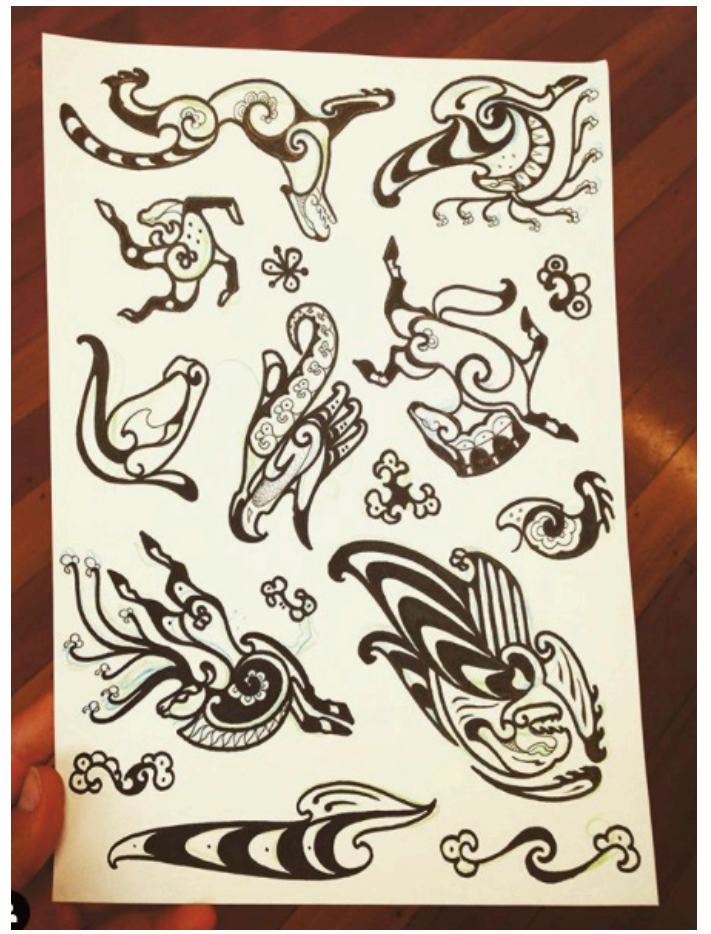

Photo 3. Danny Riday's Scythian flash tattoo designs while serving as an artist in residence at Calypso Tattoo in Willington, New Zealand. Фото 3. Шаблоны татуировок Дэнни Ридея, которые он создал, работая приглашенным художником в салоне Calypso Tattoo, г. Уиллингтон, Новая Зеландия in the name of progress - destroyed that piece of their own history and culture and now have a deep craving for something powerful, grounded and ancient." While Riday does not have any Turkic ancestors and is not aware of any direct link to the Scythian bloodline, "the art style, its history, mystery, mythological melting pot of creatures, form, flow, simplicity, complexity and stand-alone unique look are the things which drew [Riday] in. The ancient Scythians were a fascinating people. Entirely different from their neighbors, and yet, we know so little about them, and a great deal of what we do know

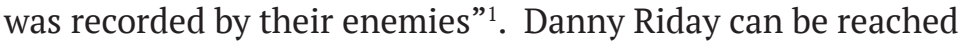
for booking at his Instagram handle Totemic_Tattoo at his home studio, Skinks Tattoo Studio in Hamilton, New Zealand. Riday is a guest tattoo artist in residence all over New Zealand and frequently creates flash designs inspired by Scythian designs, popular amongst his many happy clients, and patrons who do not have a specific design in mind prior to booking an appointment (photo 3). Riday refines his craft by learning from other artists such as Sergei Rakov, a social mediafamous tattoo artist based in Yaroslavl who has done much in popularizing Scythian stag tattoo designs in the community and around the world. Rakov's designs are an update to traditional Russian prison-style tattoos, Orthodox ikons, Old Church Slavonic inscriptions, as well drawing inspiration from Pazyryk nomadic tattoo traditions.

\section{On social media platform I n s t a gra m, a satisfied} A m e r i c a $n$ client shows off her new tattoo of the looped stag. Her tattoo features the stylized stag, with swirl embellishments at the limbs, neck, and horns (photo 4).

Accompanying the post,

«I got a new tattoo today. New to me, but it's an ancient design. This deer tattoo was found on a Scythian woman warrior that was frozen in the ice for 2,500 years... she is called the ice princess which resonates hard with a girl from the north country... This particular deer tattoo was found on numerous warriors, and always on their left shoulder. And now it's on my left shoulder too. I love that thought, of a connection between women from different worlds and times... connected only by a fierce desire to find their own limits. This will be a constant reminder to me to be deliberate and patient and afraid of nothing»(Laura @foodieknitter, 2020)2.

This personal reflection is just one instance of how getting a Scythian tattoo can help people imagine themselves in a still widely unknown culture, drawing parallels to their own lives. This kind of romantic imagining is not new and with the 2000 unearthing in Tuva, have only reached the periphery of the

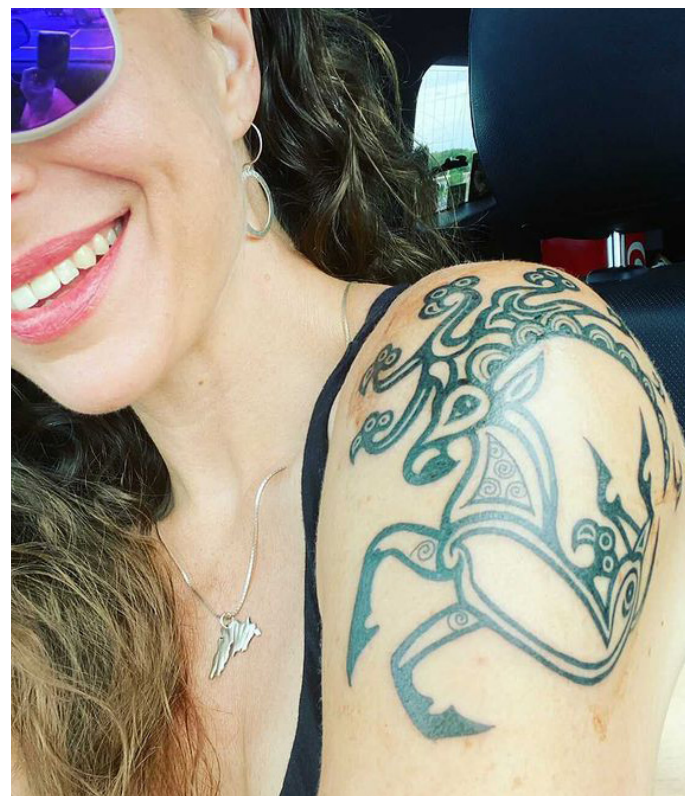

Photo 4. A Scythian stag tattoo

from Sacred Tattoo Studio

in Marquette, Michigan, United States. Фото 4. Татуировка со скифским оленем

(Sacred Tattoo Studio, г. Маркетm, uтат Мичиган, США)

${ }^{1}$ Riday, Danny. Interview. Conducted by Katherine Leung, 23 August, 2020.

${ }^{2}$ Fooditknitter. "Sacred Tattoo Studio.” // Instagram, 26 July 2020 [online] Available at: https://www.instagram.com/p/

CCyzzYnBKUV/ (accessed 22 August 2020). 


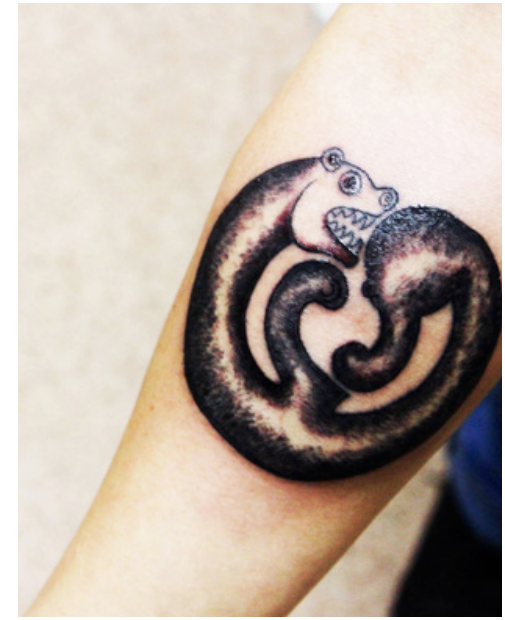

Photo 5. A tattoo on a client at Tuvtatto.

Фото 5. Татуировка на клиенте Tyв Tamy.

artists it will impact. The ideals perceived in Scythian culture encourage bravery and patience. It will continue to inspire many more. Recipients of tattoos often imbue a variety of meanings from such historic tattoo designs - even the process itself is cathartic.

In the center of Asia, adorning oneself with a Scythian tattoo is becoming a trend as well. Alexander Mongush of Tuvtattoo, Kyzyl's most well-known tattoo shop, has posted Scythian designs on both Vkontakte and Instagram (photo 5). Tuvtattoo is one of three tattoo parlors in Kyzyl. Tuvtattoo is onepart tattoo parlor, one-part barber shop and self-taught designer Mongush does it all. He even dabbles with music and video producing, which he promotes his tattoo artistry through catchy videos directed at young people on his Youtube channel. His videos are fun, his crew don street wear, blast underground chill-hop DJ mixes typically heard at any poolside party in Los Angeles or New York City, and exude a laid-back vibe that typically accompanies any other "hype" artist in both Europe and Asia. Mongush is part of the new up-and-coming crop of new artists in Tuva, exactly the kind of talent that brings Tuvan culture and art to the mainstream, even if it is not entirely "Tuvan" in the traditional sense. Mongush uses social media to stay connected with his clients, from posting progress photos, holding contests, and innovative campaigns, from student discounts to generous free ink sessions for young people who bring groups of their friends into the shop.

From a quick look at his Instagram and Vkontakte accounts, the majority of his designs are contemporary tattoos that are not particularly Russian or Tuvan in nature. Some of his designs are inspired by neotraditional styles featuring snakes, roses, and birds. Many have English words. Lions, Japanese kanji and Chinese characters, lotus flowers, mandalas, and minimalist tattoos are present in his ever-changing portfolio, proof that Tuvan taste is not unlike the rest of the world. Mongush shares that the most popular design in his shop is a Tibetan mantra. Men typically request samurai and dragon imagery. Women request flowers, such as peonies. Mongush's clientele rages from as young as eighteen to as old as sixty years of age.

A piece that pays respects to Scythian culture Mongush tattooed in 2016 is a small minimalist stag (photo 6). While it is not entirely identical to the symbol that adorns the Tuvan National Museum, the update to this classic reference is noted. The tattoo is perhaps a reminder to the recipient of the grandeur and legacy that

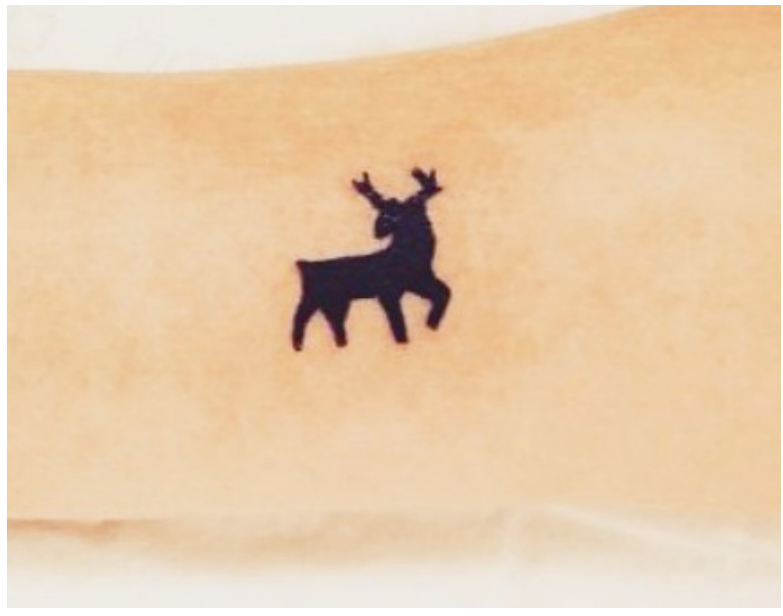

Photo 6. A tattoo on a client at Tuvtattoo,

shared by Alexander Mongush, @tuvtatoo_zg on Instagram. Фото 6. Фото татуировки на клиенте ТувТату, размещенное Александром Монгушем в Инстаграме @tuvtatoo_zg. came before, or even an appreciation for Central Asian fauna, a reindeer herding tradition in the region that is centuries old. Mongush has shared that he has drawn sketches and have received requests from potential clients wanting Scythian designs, but have yet to book a session with him. He is still in talks with many perspective clients. By reworking the traditional stag into a block design that is contemporary, he reinvents tradition so that it is relevant for young people. Showing the stag in a new light is one way to make sure the traditions of the culture before does not perish.

When interviewed, Mongush said "in our republic, tattoo culture is still developing. People's attitudes are not like those in other [larger] cities. However, many young people have already taken interest" ${ }^{1}$. So much work is being done on behalf of artists and liberal-minded young people who want to destigmatize tattoos and tattooing. Artists like Mongush help many see that tattooing is an artistic discipline worth respecting. It is a centuries-old art form that truly comes from the people, for the people, with expert precision unique talent, and dedication to make a career possible.

${ }^{1}$ Mongush, A. Interview. Conducted by Katherine Leung, 3 October, 2020. 
For tattoo artists in the West like Danny Riday and Christi Wild, Scythian designs like the stag offer a window into the past, through reimagining. People recognize that there is cultural knowledge from that time that they would like to reclaim. Tattoo artists act as mediums for people to reconnect with that narrative. For tattoo artists in Tuva, like Alexander Mongush, tattoos are a means for Tuvan people to adopt liberal ideals. From building his own business, to including young people in his craft, it is a new means for community building through arts. It is interesting this juxtaposition with Scythian designs and tattooing exists inside and outside of Central Asia.

\section{The Scythian stag in high fashion}

The Scythian stag is represented in high fashion, on runways across Europe and Asia.

Elen Godis is a Ukrainian fashion designed based in Odessa. She is the director of Studio Elen Godis and her work has been featured in Ukrainian, Odessa, Bucharest, Lviv, and Rome Fashion Week; in addition to Dnepr Fashion Weekend, Fashionable East Białystok, Red Carpet Düsseldorf (Germany), and Mercedes-Benz Fashion Days Kiev. Her works are published in British Vogue and her "Scythian Gold" collection was a mainstay the Odessa Fashion Week 2018. Godis attended Odessa Polytechnic Institute, boosting her past technical education as "the perfect knowledge of geometry and practice, practice and again practice - these help to produce new creative forms and use the latest technologies," at times even "when one material is replaced by another, us[ing] leather instead of metal"

One such necklace in her Scythian Gold collection contains a leather strap and suede metallic medallions, embroidered with the pattern of an animal on each medallion. At the center of each of the eight laser cut circles is a metal pin. She juxtaposes textures again in a statement necklace, and acrylic accented leather trapezoidal bib featuring the embossed image of the icon stag, looped horns and angled legs, as if in motion. Godis's Scythian Gold collection includes bangles, chokers, and various gold colored statement pieces, all sewn onto leather. Each bauble is lightweight and original leatherwork, blurring the lines between contemporary fashion and prehistoric burial jewelry - not unlike the pieces found in Arzhaan II. In an interview with Odessa Fashion, Godis shares that she uses actual images of Scythian gold accessories, to "create true copies of the elements of these products... assembl[ing] the elements at my discretion" ${ }^{2}$. While not claiming to be of Scythian lineage, she acknowledges that the imagery impacts contemporary life in a tangible way, and honors that in her designs. Her designs are critically acclaimed and sold in boutiques across Ukraine, as well as in her own show room. Instead of romanticizing a past, the wearability of her pieces represents an attitude of strength, grace, and beauty as aspects of modern life, something that anyone can relate to.

Godis is not the only one to realize the stag in couture. Vyacheslav Dongak is a Tuvan fashion design who has used Scythian imagery in his designs. Nowhere near the end of his career, sexagenarian Dongak has served as the Minister of Culture and Tourism of the Republic of Tuva for over ten years. Appointed by Sholban Karaool in a plea to reform culture, as "the face of our republic," he is still an active design powerhouse in Tuva ${ }^{3}$. In addition to fashion design and public service, Dongak has an extensive background in performance art.

Throughout his career as a choreographer, Dongak has served as the artistic director of the Inner Mongolia National Art Theater, arts teacher at Republican Legal Lyceum, and more. He was awarded as an Honored Worker of Culture in 1997 and appointed a State Prize Laureate in 2004. At age nine, Dongak began studying dance at the Buryat School of Choreography, later perfecting his craft at the Russian Institute of Theatre Arts in Moscow.

Since 1974, he was a part of the Sanyani Dance troupe until he used his mastery and expertise to chart his own path - creating his own chorography company, Edegey. Edegey dancers and choreography have become household names for what many Tuvans consider traditional dance art. Dongak is known for his intricately complex set and costume design, a celebration of traditional concepts with one-of-a-kind textiles, which visually compliments each performance. His designs bring inspiration to other Asian and Turkic republics

\footnotetext{
${ }^{1}$ About the Brand. Elen Godis [online] Available at: https://elengodis.com/about-the-brand/ (accessed 22.08.2020); Elen Godis. Scythian Gold. Youtube, 27 November 2018 [online] Available at: https:/www.youtube.com/ watch?v=KFKC2euYZUM (accessed 22.08.2020).

${ }^{2}$ Elen Godis. Scythian Gold. Youtube, 27 November 2018 [online] Available at: https://www.youtube.com/ watch?v=KFKC2euYZUM (accessed 22.08.2020).

${ }^{3}$ Донгак О. Донгак Вячеслав: Не выживать, а достойно жить [Электронный ресурс] // ИА Туваонлайн, 2007, 9 июня. URL: https://www.tuvaonline.ru/2007/06/09/0057_dongak-int.html (accessed 22.08.2020).
} 
in reimagining what it means to bring traditional dance and costume to the twenty-first century. Edegey is entirely self-funded and privately-run, with dancers as young as five participating in the rigorous year-round show troupe, performing worldwide. The success of Tuvan art has been partly attributed to Dongak, whose international events such as Edegey's 2009 performance in Paris area requirement in promoting Tuvan cultural diplomacy ${ }^{1}$. For a republic so small in a country still largely unknown to outsiders, the Edegey dance troupe plays a crucial role in international soft power hegemony.

With his dance performances, Dongak partakes in inventing a tradition, romanticizing a past similar to tattoo artists. Although a common belief is that dance was not a part of Tuvan-folk life, Dongak has said in an interview,

«I strongly disagree with the myth that Tuvans did not have dance in our traditional culture. Each nation has its own special rhythm, movement, and they are the basis on which any production is built. In Tuva, I am inspired by everything: even the movements of an eagle are the embodiment of courage and the joy of victory. I constantly try to reflect the beautiful nature of Tuva, both in the versatility and understated quality of the Tuvan people» ${ }^{2}$.

He recognizes the role of his choreography and dancers in paving a new way for how Tuvan culture is perceived by outsiders. He fantastically constructs a narrative, with great acknowledgement to Tuvan traditions. The debate

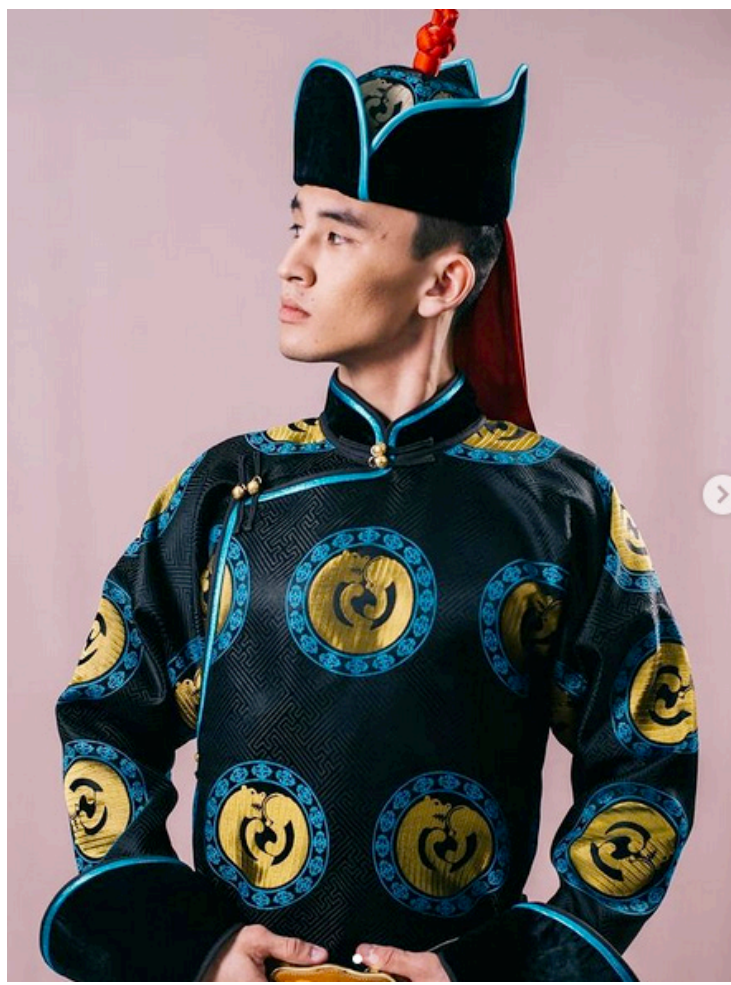

Photo 7. One of the outfits for rent advertised on the @brand_dongakInstagram page.

Фото 7. Реклама одного из костюмов для сдачи напрокат (с Инстаграм-страницы @brand_dongak) whether this practice of inventing tradition is disrespectful or not goes on in private spheres between purists across Tuva, though it has allowed foreigners to interact with Tuvan culture for the first time - through Dongak's blissfully imaginative, stylistically dazzling, ornately constructed choreographed performances.

Dongak is a multidisciplinary artist like no other, with a prolific resume. Other than dance, he and his family manage a successful fashion design company. By 2012, they oversaw more than fifteen collections. His wife, Kima Dongak, is the director of their fashion line, Ovaadai, and one of his daughters, Ayana Saaya, is the art director. They employ in-house seamstresses and market their designs out of their own atelier, where the entire design-to-runway process is streamlined. Their very first collection was "Asian Motives" in 1999, immediately recognized in a High Fashion Folk Costume contest in Moscow. Since then, they have had a months-long waitlist of eager fashion enthusiasts who desire their own Ovadaai pieces. Their design studio takes no private commissions as they pride in the originality of their work. However, they do rent out outfits by the day, at 3500 rubles, that include a tailored suit, hat, belt, and boots (photo 7). Dongak sources materials from all over Europe and Asia, and never rely on middlemen for fabrics or artistry. A seamstress at Ovaadai sews up to sixteen stage costumes for the Edegey dance troupe every month. From Doangak's original sketch to the sewing process, all the way down to the rehearsal and performance, the entire process is precise and overseen by the Dongak family (Tyukhteneva, 2018).

In 2020, Dongak outfitted Russian singer Ruslan Ivakin, also known as Gurude, for a concert. Ivakin is also a state-recognized arts laureate, like Dongak. Gurude's music is a fusion of folk, throat-singing, and electronic, citing the organic link. He has performed all over the world, embodying a sort of neo-pan-nomadic identity, idealizing what is modern steppe culture. In the costume Dongak designed for Ivakin, traditional animal pelt is used (photo 8). He used his iconic embossed, double border to draw the silhouette in Ivakin's costume, typical of Tuvan national dress. Dongak choose brown silk as a canvas and placed gold-stitched looped stag on the sleeves. The effect is romantically visceral - Ivakin's arm looks as if deer are is constant motion moving

${ }^{1}$ Ibid.

${ }^{2}$ Мукатова К. Вячеслав Донгак: «Я категорически не согласен с версией, что у тувинцев не было танцев» [Электронный ресурс] // ARD, 2015, 24 августа. URL: http://asiarussia.ru/persons/8791/ (accessed 22.08.2020). 


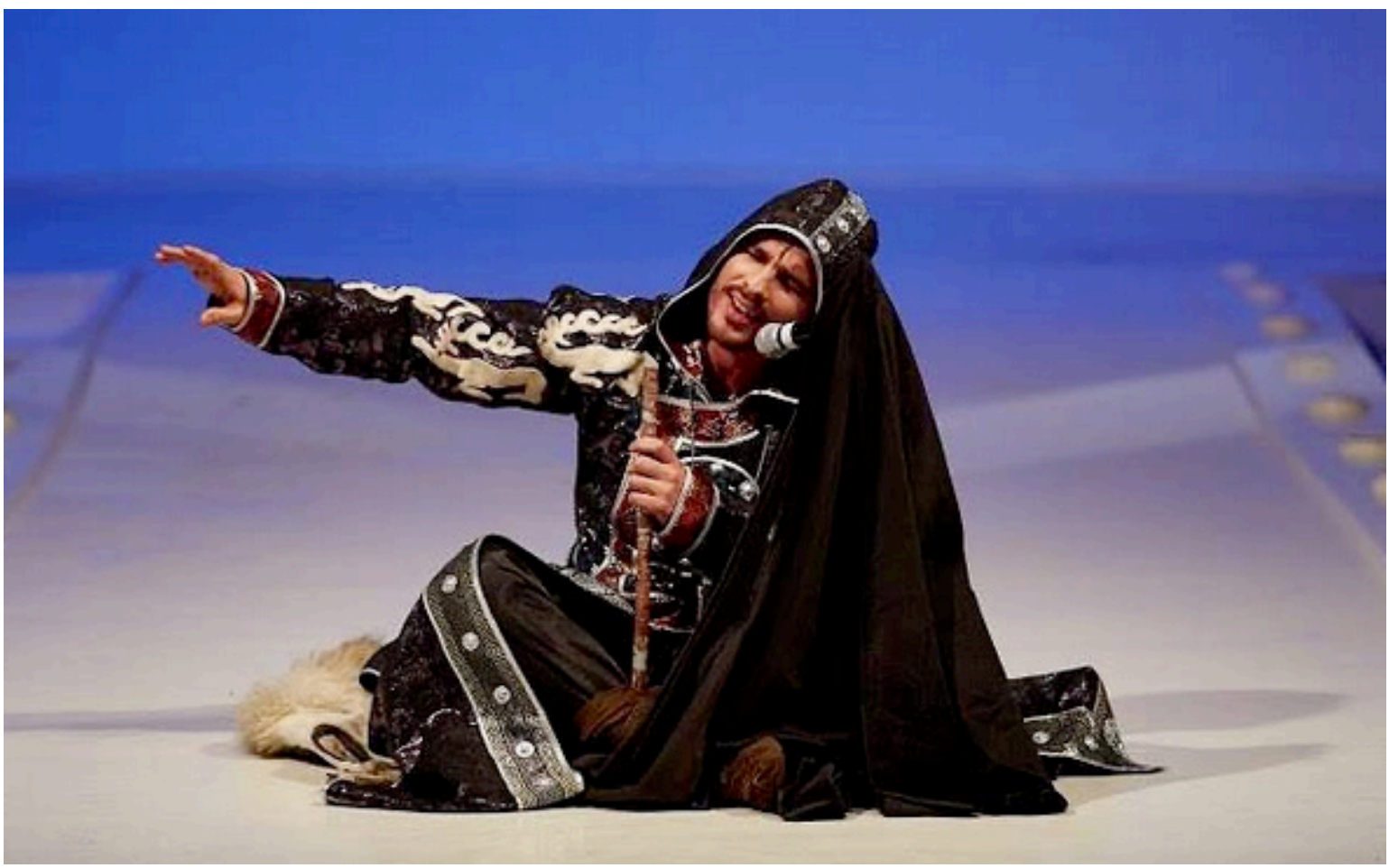

Photo 8. Singer Gurude wearing Dongak's design

Фото 8. Певец Gurude в сценическом костюме, созданном по дизайну Донгака.

through his body, blurring the perception of spirit in Ivakin's voice, movement, and performance. Dongak also chooses to include a hood and veil in the costume. This design is a conglomeration of many nomadic cultures and textile traditions, infused through romantic imagining.

National dress has always been a source of controversy among Tuvans. People have long criticized Dongak for distorting the national costume in his designs. The Tuvan national cap is commonly argued to be different from the Mongolian and Manchu style in specific ways, as well as the intricacies of the cloth belt that ties the robe together.

\section{Dongak tells his critics,}

[My designs are] our traditional national costume. The national costume has not gone anywhere. This is history. Everything does not resist change for centuries. The national costume should be adapted. This is what we are doing today. We transform and develop the national outfit. If you are a type of Tuvan that wants to only wear what our ancestors wore a hundred years ago, then why then do you live in a comfortable apartment and drive a car? Then live in a yurt and ride a horse. As our consciousness develops, so should our costumes ${ }^{1}$.

At Ovaadai, it is not merely about adhering to tradition, it is about creating both an experience for the wearer and viewer. He applies this same principle in the symbols found on his designs. While the discovery at Arzhan-II was not documented until the twenty-first century, he places "new" symbols on Ovaadai textiles that are meant to reproduce eighteenth and nineteenth century stylized Tuvan national costume.

It wouldn't be Tuvan without a little superstition. Dongak cites that all his designs bring good luck. Only a few models demonstrate "strength and character" suitable for each costume so there are numerous fittings before the costume even comes to life. His models are meticulously selected to his standards, a standard so high that Dongak has created his own modeling agency². In February 2020, Dongak started an initiative to find Tuvan ethnic models to place in the Asia Model Festival in Seoul, South Korea. While COVID-19 cut the contest short, Dongak has not stopped searching for models in the republic, many from his own dance troupe Edegey. This Tuva-based modeling agency is the first of its kind and continues to promote fresh Asian faces on social media, teach makeup workshops, provide training, mentorship, and more.

${ }^{1}$ Кондрашова В. В закулисье у тувинского кутюрье [Электронный ресурс] // Tuva.Asia, 2012, 18 февраля. URL:

https://www.tuva.asia/news/tuva/4457-kutyure.html (accessed 22.08.2020).

${ }^{2}$ Ibid. 
One of his models, Ayan Kuular is a talent that Dongak has discovered and heavily promotes through social media. Kuular also takes part of the Edegey dance team, representing Dongak's choreography and costumes all around the world. After a competition in Osh, Kyrgyzstan, Kuular shares this photo on Instagram (photo 9). Pictured, Kuular is wearing a masculine-type armor; metal plates line his wrists and belt; and broad shoulder pads embossed with intricate metalwork and studs, with modern buckles keeping the shoulder pads in place with the breastplate. His sleeves are a deep red, stylistically loose, puffy and lined with various silk ribbon. His belt contains large silver buckles, depicting men on horseback. This is a fashion statement and certainly not an item someone would wear to battle, but reveals the genius of the dual worlds Dongak's designs navigate. Kuular models this costume with pride, next to the Tuvan national flag.

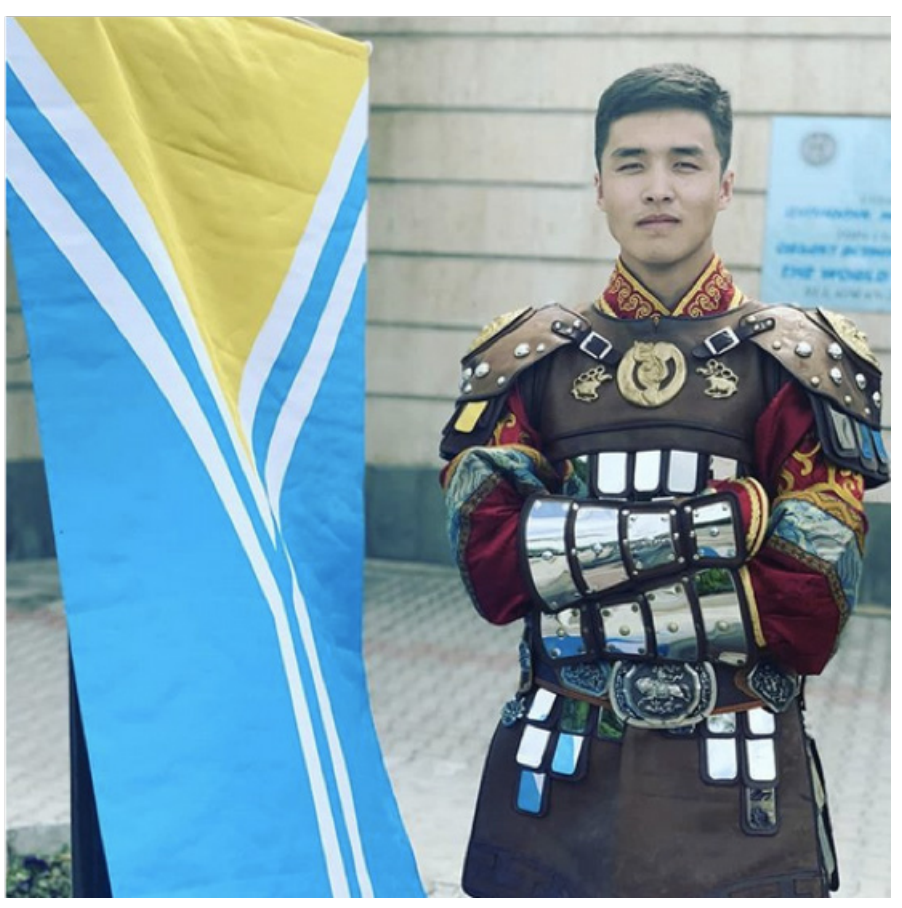

Photo 9. Edegey dancer Ayan Kuular in Osh, Kyrgyzstan, 2020. Фото 9. Танцор труппы «Эдегей» Айан Куулар. Кыргызстан, г. Оu, 2020

Dongak's fashion designs diverge from tradition in a few ways. For example, in one of the menswear national dresses he has created, he uses light blue and yellow. These are relatively new colors and part of Tuvan national statehood to the Soviet Union and Russia. The idea of yellow and blue going together is considered contemporary and not often found in a traditional dress. In Dongak's Instagram post as recent as January 2020, he features the Scythian jaguar in the repetitive silk design. This artifact was not found until the early 2000's from an excavation, so it is also not "traditional" in the sense that it is not a recurring motif used on national dress. The point in the national cap is made with a string and intricate knot, again, a newfound aesthetic that is unique to Dongak's creations. Historically, there was distinct "battle" and "celebration" wear - and as seen in Kuular's social media post, Dongak has blurred the lines, inventing tradition, once again. Regardless, Dongak is an artist that has brought Tuvan culture to many countries through his numerous projects. His update to the tradition is reflective of the dynamic Tuvan population. Including Scythian symbols in his designs is an artist's appreciation and acknowledgement of Scythian roots and the iconic stag that emerged from the excavation, but also a statement that modern Tuvan identity is a conglomeration of geography and romantic imagining of legends and folktales. This is not unlike the reimagination Alexander Mongush does as a Tuvan tattoo artist.

\section{The Scythian stag in Western folk crafting}

The next examples illustrate how the Scythian stag has been reevoked in folk art.

Australia-based Hungarian artist Boroka Égerházi-Kis is the owner of the Felt Nomad shop and created a life size felt stag mask in 2018. The mask is made entirely of wool-felt and leather, "expressed in the most ancient textiles" ${ }^{1}$, with sturdy looped horns in a blend of off-white and brown. The looped horns are almost an exact replica of the intricate design of the original gold design. Her design is completed in felt applique, which Égerházi-Kis cited as a Scythian technique.

"The loop horns are actually eagles, the stag itself is the symbol of the tree of life, the magical deer, and among the branches of that tree or its antler eagles are nesting, who are going to take the souls of the people back to the earth when they are ready to reborn in a new body," Égerházi-Kis shared in an interview².

\footnotetext{
${ }^{1}$ Égerházi Kis, Boróka. felt_nomad. Instagram, 20 April 2020 [online] Available at: https://www.instagram.com/p/ BhyY1cBH3fo/ (accessed 22.08.2020).

${ }^{2}$ Égerházi-Kis, Boroka. Interview. Conducted by Katherine Leung, 23 August, 2020.
} 


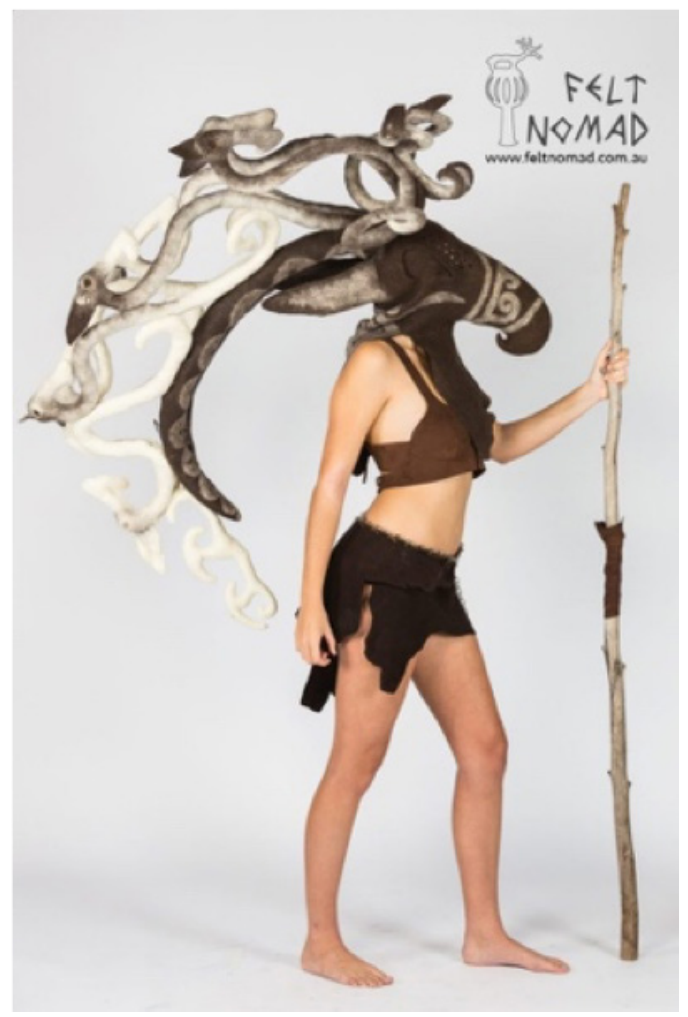

Photo 10. The Sorceress by Boroka Égerházi-Kis of Felt Nomad, at Wearable Art Mandurah 2018. Фото 10. «Колдунья», автор Борока Эгерхази-Киш, магазин Felt Nomad, на выставке Wearable Art Mandurah 2018.

her site and artist persona name (photo 11).

This costume was originally created for the Mandurah Wearable Arts Awards and available for commission in the Felt Nomad shop in Australia (photo 10). While Égerházi-Kis is originally from Hungary, she has been living in Perth, Australia for over a decade and currently working on her third master's degree. She is fascinated with Scythian cultures and sees ancient Scythians as "ancestors of the Hungarian, Hun, Avar, Sarmata cultures, all that lived in those steppes... and in the territory of Hungary" for thousands of years ${ }^{1}$.

Égerházi-Kis shared herself adorning the mask on social media, accompanied with a short fantastical vignette: "from the Cave of Trois Fréres to the Scythian tattoos and golds here the Magyar Sorceress starts to wander, the Tree of Life is its antler where eagles are nesting to bring the reborn souls back to Earth"2. Akin to cosplay, which is typically done with fictional pop-culture characters, Égerházi-Kis creates a story and depiction that is personal as much as it is imaginative.

In April of 2018, the artist wrote,

«Just realized, that although Scythians lived throughout a giant part of the world, they never conquered anyone. They became friends with neighbors, and shared knowledge. That's how it should be. Wonder where are they now, because they've been attacked by many, mostly were standing strong» ${ }^{3}$.

In other posts shortly before the creation of the felt stag mask on Égerházi-Kis's social media, the artist posts photographs of Scythian artifacts with identification hashtags, such as \#shamanstick and \#cheftainstick. Such ideals are influenced by modern Tuvan practices of shamanism but also by an idea that is present in many nomadic, pagan cultures around the world, evidently a practice Égerházi-Kis pays homage to her in

Aliza Souleyeva-Alexander is a Canadian silversmith and lapidarist, sold at SoulEyeJewelry, an Etsy e-commerce handmade shop based in Victoria, Canada. She creates original metal works that contain the iconic stag (photo 12). Originally from Almaty, Kazakhstan, Aliza received her Master's in art and textiles from Zhurgenov Kazakh State Art Academy. As of 2020, her online boutique has not been open for more than three years but has received over 120 sales, in addition to countless commissioned purchase orders. The price of her hand lapidated pieces begin at $\$ 20$ and go up to $\$ 280$, no doubt selling for more when customers request custom pieces. Souleyeva-Alexander writes that her soldered amulets and customized jewelry pieces are examples of "self-expression influenced by personal values, emotions, and the surrounding environment". SouleyevaAlexander also shares with her twenty thousand followers source photographs of the golden Scythian stag, educating them on her intentions and their aesthetic meaning to herself. "It symbolizes the source of light and life as well as a noble soul”, she writes in an Instagram Story titled Inspiration. In both her Etsy and Linkedin profile, she shares about being a mother of two. Perhaps her identity as an artist is intertwined with the stories and idealized culture she wants to pass down to future generations.

${ }^{1}$ Égerházi-Kis, Boroka. Interview. Conducted by Katherine Leung, 23 August, 2020.

2 Égerházi Kis, Boróka. “felt_nomad. Instagram, 7 April 2018 [online] Available at: https://www.instagram.com/p/ BhQtuVonS6y/ (accessed 22.08.2020).

${ }^{3}$ Égerházi Kis, Boróka. “felt_nomad. Instagram, 17 March 2018 [online] Available at: https://www.instagram.com/p/ BgcwddUHDFz/ (accessed 22.08.2020).

${ }^{4}$ Souleyeva-Alexander, Aliza. Linkedin [online] Available at: https://ca.linkedin.com/public-profile/in/alizasouleyeva-alexander-994a8b14? challengeId=AOGJCaQ-nrLOowAAAXOZkJP16bkuPmz-LjfiscdOOYEdpm3GijObnCw nRl1kDxNRJoenugOh6-dCTq6x41E_i4YfXr16IJetw \&submissionId=1a38534b-16cb-2d16-49f4-cbdb346b4448 (accessed 22.08.2020).

${ }^{5}$ Ibid. 


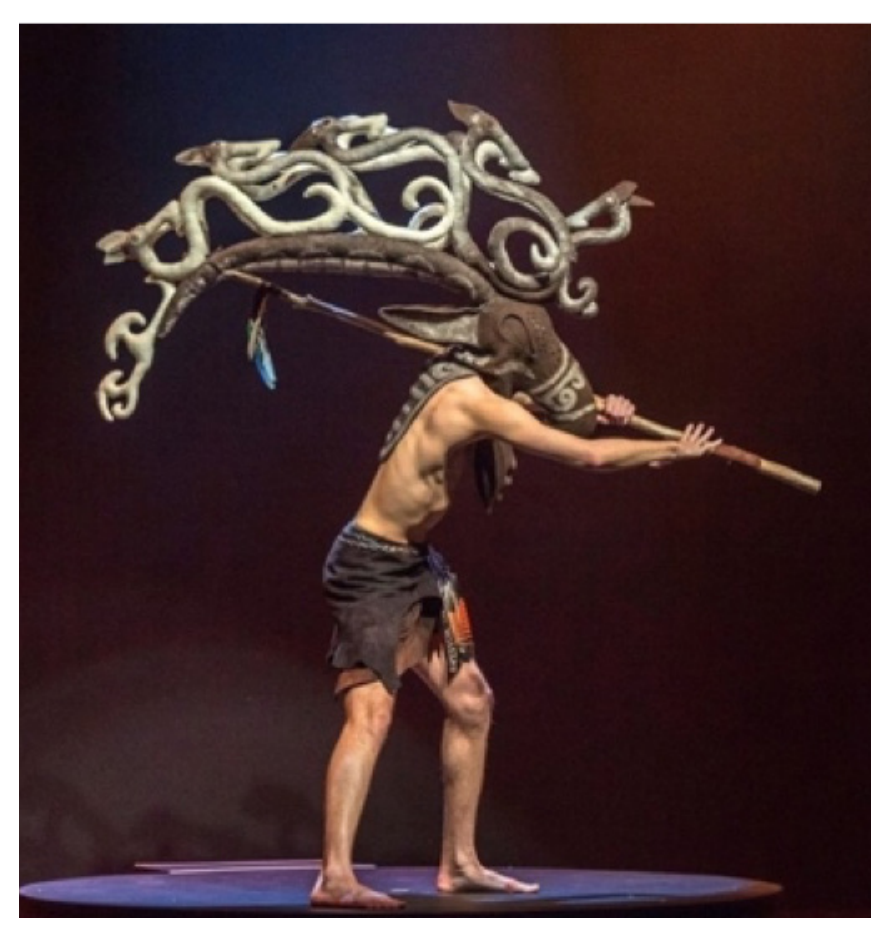

Photo 11. The Sorceress by Boroka Égerházi-Kis of Felt Nomad, photographed by Stephen Heath

Фото 11. «Колдунья», автор Борока Эгерхази-Киш, магазин Felt Nomad, фото Стивена Хита

\section{The Scythian Stag in Tuvan Folk Crafting}

Folk crafting at the end of the nineteenth century in Tuva typically took the form of carved wood. Larch was one of the more popular types of wood Tuvan craftsmen made decorations, eating utensils, instruments, and furniture of. Although many types of wooden applied arts emerged from the Russian speaking world at this time, Tuvan craft is a genre in its own right thanks to the contributions of well-decorated pioneering stonecutters from the Tuvan ASSR.

One of the most well-known artists that put Tuvan stone cutting in the Russian decorative arts canon is Hertek Kashtayovich Toybuhaa. Toybuhaa, born in 1917 in the Barun-Khemchik region, created a poplar wooden race horse at the age of eight and worked as a veterinarian for thirty years. This multidisciplinary artist's most famous work is "Maraluka with a Calf" (1963), a concrete monument still found on the Kyzyl-Abakan highway and has become a symbol synonymous with the region. Toybuhaa's legacy can be seen at one of the most well-known arts school in the republic, the Bai-Taginsky Children's Art School, now named after him (Dorzhu, 2012).

Carving Serpentinite was also a popular folk craft in Tuva, where this hardy mineral is locally mined. One renowned artist known for his creations with Serpentinite is Cherzi Mongush. Born in 1899 to a family of laborers in Ak-Turug, and raised by his grandfather who specialized in Tuvan aptara chests. By age eight, he was able to independently carve wooden horses, sheep, and other animals. His work in the 1950s was exhibited at numerous venues in Kyzyl. Throughout his career, he created over 1,000 sculptural works of wood and stone, many which are archived in museums in Moscow and St. Petersburg. In 1962 he foun-

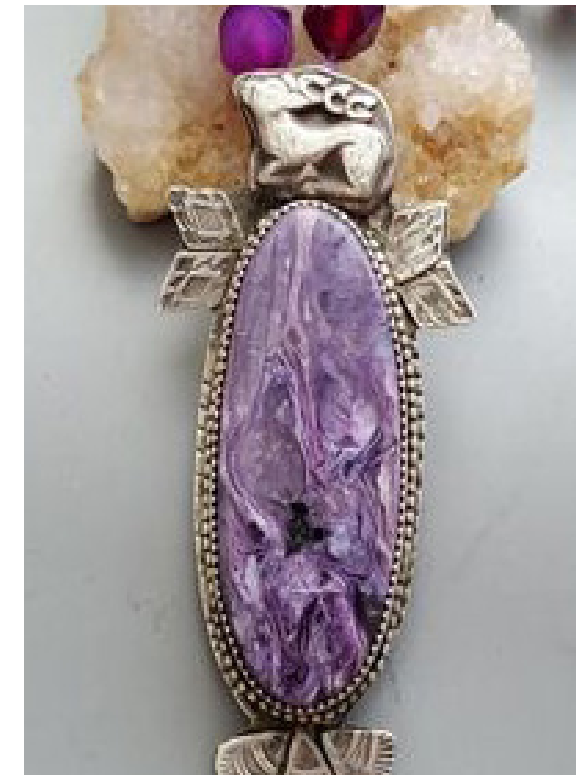

Photo 12. An image of silver set Charoite pendants with Scythian stag, hand knotted faceted sea sediment Jasper and diamond cut agate on double hemp cord, 18 inch in length with two lobster clasps to clip on and off the pendant.

Фото 12. Набор подвесок из чароита со скифским оленем, морской осадочной яшмой и резным агатом на двойном пеньковом жгуте длиной 45.75 см. Подвеска застегивается двумя защелками из панциря лобстера. 
ded an organization of applied arts, where he taught young stone cutters from all of Tuva until his death in 1969 , at the age of $70^{1}$.

The most prolific folk carver was Dongak Okaanchik. Born 1896, Okaanchik started out imitating the works of his father and brothers, who were also stone cutters, in wood and metal. Most of Okaanchik's works were created from cedar and pine, and he made Tuvan yurt accessories, but most notably, Tuvan national instruments such as the igil, a bowed two-string instrument of pine or larch; chadagan, a plucked zither with sixteen strings; and dopshuluur, plucked instrument with two strings. Often decorated with flowers and butterflies, relief images are carved onto the side. Although sent to the Siberian GULAG camps for a period of time, Okannchik's work and legacy is still memorialized in Tuva as being an artist of the people. Okaanchik's grandchildren are all respected members of Russian society, some even teachers. Many of his descendants came together in 2018 to arrange an exhibition at the Tuvan National Museum for the $120^{\text {th }}$ anniversary of Okaanchik's life and the Interregional Sculpture and Wood Carving Symposium: Wood Carving and the Creations of the Central Asian Masters². The exhibit honored Okaanchik's brothers, also artists, with a display of their wooden dishes, beds, carts, sleighs, buffets, and aptara chests. In 2017, the first annual state-run carving compe tition was put on in Okaanchik's name.

Tobuhaa, Mongush, and Okaanchik were all Honored Artists of the USSR, inducted into the USSR Union of Artists, and Tuvan People's Artists, among other awards ${ }^{3}$. Interestingly, in the official biographies of all three artists, mention of their talent being discovered early in life is significant, perhaps a trait in Tuvan story-telling. Their work all consisted of animal imagery, both domesticated and wild. Depictions of animals are not a phenomenon seen only in Tuvan applied arts, but have come to characterize folk art from this Siberian region. Lastly, regard for their sculpting is passed down through education. Applied arts, while quickly becoming labeled as an antiquated practice, anachronistic to "village life," is carefully preserved and routinely celebrated in Tuva. Tuvan school children are taught the works and techniques of the masters, and that preserving such traditions ensure the relevance of tradition will persist. Contests and exhibitions keep the interest alive $e^{4}$. While not professional educators, all three masters certainly had apprentices, as well as students, who teach their life and works, and perpetuate interest in their arts with arts foundations and traveling exhibitions.

One such educator is Maxim Ochur-Badievich Lopsan, a collector and teacher of folk carvings who has donated many of his priceless works to the Tuvan National Museum - most notably the ten units of carvings made from tree burls. Burls are abnormalities in the wood grain that result in a rounded outgrowth, commonly found on tree trunks. They are said to be resistant to splitting and strong as stone; and typically found on oak, birch, poplar, maple, apple and aspen ${ }^{5}$. Lopsan is active in the decorative arts community, and served as both a teacher and director of the award-winning Children's Art School in Mezhege Village ${ }^{6}$. He has played a major role in keeping the tradition of wood carving alive, in post-Soviet Tuva, through his leadership in many arts initiatives, such as contests, at the school level.

The efforts of artists and art patrons do not go unnoticed. Tuvan school and university students continue the tradition of carving. In the fall of 2020, at the height of the COVID-19 crisis, Tuvan State University hosted Family Architectural Hackathon, an outdoor art exhibit and opening reception of over seven new benches installed in the Youth Park (Molodezhnyi park). The benches were created by a group of students in the Na-

\footnotetext{
${ }^{1}$ K 120-летию легендарного тувинского мастера-камнереза Черзи Монгуша [Электронный ресурс] // ИА Туваонлайн, 2018, 20 сентября. URL: https://www.tuvaonline.ru/2018/09/20/k-120-letiyu-legendarnogo-tuvinskogomastera-kamnereza-cherzi-mongusha.html (accessed 22.08.2020).

${ }^{2}$ Ibid.

${ }^{3}$ Назым Доржу. В Туве отметили 95-летие выдающегося камнереза - Хертека Тойбухаа [Электронный ресурс] // ИА Туваонлайн, 2012, 2 февраля. URL: https://www.tuvaonline.ru/2012/02/02/v-tuve-otmetili-95-letievydayuschegosya-kamnereza-herteka-toybuhaa.html\#sel=11:1,11:19 (accessed 22.08.2020).

${ }^{4}$ Результаты I республиканского конкурса по деревянной резьбе им. Донгак Окаанчык [Электронный ресурс] // Tuva24, 2017, 24 июля. URL: http://tuva24.ru/news.php?id=24647 (accessed 22.08.2020).

5 Природа и человек творят чудеса (о коллекции сувениров из капа в фондах Национального музея Республики Тыва) [Электронный ресурс] // www.facebook.com/tuvamuseum, September 30, 2020. https://www.facebook.com/ tuvamuseum/posts/2790027461275585 (accessed 22.11.2020).

${ }^{6}$ Подведены итоги III Республиканского профессионального очного конкурса среди преподавателей художественных дисциплин детских художественных школ и школ искусств Республики Тыва «Сарыг-Хаянын салгыны» [Электронный ресурс] // https://vk.com/public186374738, 23 November 2019. URL: https://vk.com/wall186374738_246 (accessed 22.08.2020).
} 
tural Science Faculty led by a staff mentor. Students designed, created, and installed benches to represent the many common Tuvan surnames such as Ondar, Oorzhak, Kuzhuget, Khomushku, Mongush, Dongak, Kuular, and Soyan. Partly folk revival activity, partly a new take on art exhibitions in the COVID-19 reality, and partly a tradition rooted in both Tuvan and Russian crafting, this bench exhibition is another example of how wood handicrafts stay relevant in the twenty-first century. Outdoor benches are needed more than ever. Beautifying parks is still a practice local government continually address. Forgotten parks get a new life in COVID-19 and revive what it means to be Tuvan in public works.

One such bench pictured features a Scythian stag, in the same style as the logo of the National Museum

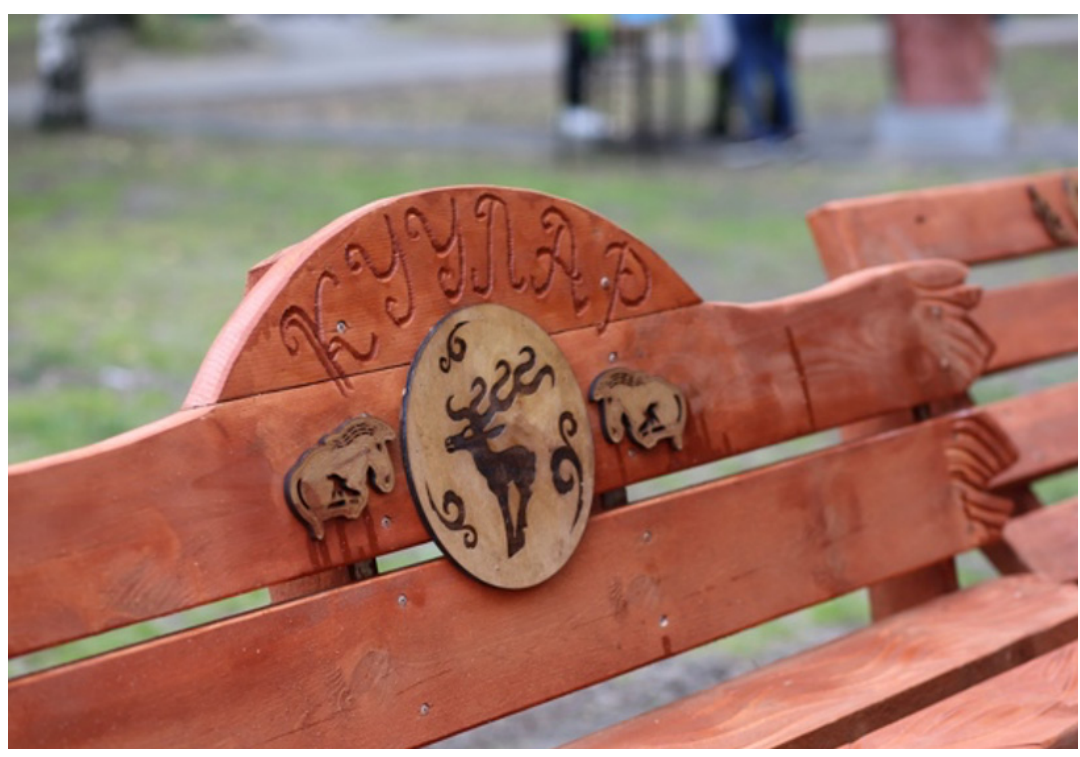

Photo 13. One of the benches created by the Natural Science Faculty at the Tuvan State University.

Фото 13. Одна из скамеек, созданных студентами естественно-географического факультета Тувинского государственного университета. (photo 13). In exploring lineage, students created benches and added symbols that spoke to their ancestry. While the surname "Kuular" cannot be traced back specifically to any Scythian archive or record, these symbols are blurred for modern day Tuvans as they all contribute in the Tuvan origin story. Wood carving fit in the broader context of both official and private efforts to support folk crafting in Tuva, and provided opportunities for cross-fertilization when it comes to identity and story-telling.

\section{Conclusion}

Artists across traditions and cultures are drawn to the looped stag, an iconic image from the Arzhaan II archeological discovery. This article highlighted the work of Russian photographer Andrei Bronnikov in documenting, preserving, and sharing the gold findings from Arzhaan II. Because of his work, other artists can come to an understanding of the looped stag through observing these gold pieces, even outside of Tuva. To reduce interpretation to university scholarship is to limit the cultural impact on identity and art. Exploring what cultural products come out of this motif is important to understand the artistic breadth of this simple symbol. Artists participate in cultural reimagining all the time, even of cultures that have taken on mostly mythological meanings.

This article discussed how American tattoo artist Christi Wild created a Scythian stag tattoo almost identical to that of the cult-famed Siberian ice maiden and depicted a happy customer who imagines herself as being shielded, empowered, and somehow connected to a mythical Scythian lineage. Both tattoo artists Danny Riday in New Zealand and Alexander Mongush of Tuva both have created Scythian inspired tattoos for clients, for varying reasons. As a Tuvan, Mongush is a type of prolific artist that draws from contemporary trends to create cherished art works in his republic. Mongush also offers contemporary people a way to reexamine their past, through Scythian symbolism.

Artists are drawn to the history, but they also at times, reinvent a historical narrative that fits their own lifestyle. For Tuvan culture to sustain, it is crucial that translatable, transportable, and transferrable artifacts, such as the looped Scythian deer, get meaningfully interpreted in the imagination of artists everywhere. If the original purpose is unknown, then at least examining the impact speaks to the potency of narrative capabilities. Ukrainian fashion designer Elen Godis and Tuvan choreographer, modeling agent, and fashion designer Vyacheslav Dongak use the Scythian stag similarly, to imagine what the past would be like, by creating textile pieces meant to be worn by many. Both draw from Scythian ideals to dress modern people, rendering the looped stag a memorable motif that inspires wearers, cross-culturally, like an ancestral longing. The fact 
remains that very little is known about Scythian traditions, so when modern Tuvan artists uphold a certain narrative, it is quickly accepted as fact by outsiders.

Folk artists from other nomadic cultures evoke the Scythian stag in retelling their family and identity stories with others. Boroka Égerházi-Kis and Aliza Souleyeva-Alexander draw on this in their arts. It is interesting a retelling of a folk narrative requires a folk technique - that is lapidary and felt crafting. Folk crafting exists in the territory of both "old" and "new" practices and evoking both let the artist adopt whichever narratives fits best for their newly reinvented personas.

Wood applied folk arts continue to fascinate Tuvans, thanks to the pioneering work of artists and art patrons. The work of Hertek Kashtayovich Toybuhaa, Cherzi Mongush, and Dongak Okanchiik is passed down through educational arts initiatives, republic-wide. The open-air wooden bench exhibit in the Fall of 2020 at the Tuvan State University is proof that traditions can be reworked, and at times, made even more relevant in the twenty first century. Art leaders such as Maxim Ochur-Badievich Lopsan, collect, teach, curate, and preserve this tradition by empowering the next generation to pursue the arts. In preserving what Scythian culture can mean to youth, education plays a key role. Education, community building, organizing, and arts organizations all work together to pass existing practices onto the next generation, but can also remind them of what genius the previous generation possesses.

Cultural ambassadors such as Vyacheslav Dongak only have so much jurisdiction. It's these simple and easily reproducible symbols that are capable of spreading Tuvan culture. They have already captured the romantic imaginations of artists around the world. Tuva's claim to the Scythian looped stag is honored, if not validated, when modern Tuvan artists reclaim it.

\section{REFERENCES}

Armbruster, B. (2009) Gold technology of the ancient Scythians - gold from the kurgan Arzhan 2, Tuva. ArcheoSciences, vol. 33 http://journals.openedition.org/archeosciences/2193/ (accessed 22.08.2020).

Bunker, E. C. (2002) Nomadic Art of the Eastern Eurasian Steppes: The Eugene V. Thaw and Other New York Collections. Yale University Press. 233 p.

Farkas, A. (1977) Interpreting Scythian Art: East vs. West. Artibus Asiae, vol. 39, no. 2, pp. 124-138. DOI: https://doi. org/10.2307/3250196

Loehr, M. (1955) The Stag Image in the Scythia and the Far East. Archives of the Chiense Art Society of America, vol. 9, pp. 63-67. URL: www.jstor.org/stable/20066973 (accessed 22.08.2020).

Tyukhteneva, S. P. (2018) Etnicheskoe predprinimatel'stvo bez migratsii (na primerakh iz Tuvy i Kalmykii) [Ethnic entrepreneurship without migration: the cases of Tuva and Kalmykia]. New Research of Tuva, no. 2, pp. 149-167. DOI: doi: https://www.doi.org/10.25178/nit.2018.2.8 (In Russ.)

Submission date: $24 \cdot 10.2020$.

\section{СПИСОК ЛИТЕРАТУРЫ}

Armbruster, В. (2009) Gold technology of the ancient Scythians - gold from the kurgan Arzhan 2, Tuva [Электронный pecypc] // ArcheoSciences. Vol. 33. URL: http://journals.openedition.org/archeosciences/2193/ (accessed 22.08.2020).

Bunker, E. C. (2002) Nomadic Art of the Eastern Eurasian Steppes: The Eugene V. Thaw and Other New York Collections. Yale University Press. 233 p.

Farkas, A. (1977) Interpreting Scythian Art: East vs. West // Artibus Asiae. Vol. 39. № 2. P. 124-138. DOI: https://doi. org/10.2307/3250196

Loehr, M. (1955) The Stag Image in the Scythia and the Far East // Archives of the Chiense Art Society of America. Vol. 9. P. 63-67. URL: www.jstor.org/stable/20066973 (accessed 22.08.2020).

Тюхтенева, С. П. (2018) Этническое предпринимательство без миграции (на примерах из Тувы и Калмыкии) // Новые исследования Тувы. № 2. С. 149-167. DOI: https://www.doi.org/10.25178/nit.2018.2.8

Дата поступления: 24.10.2020 г. 